UDC 338.4:61

JEL Classification: I11, M31

http://doi.org/10.21272/mmi.2019.1-11

\author{
Nduka Chinedum, \\ Michael Okpara University of Agriculture, Nigeria \\ Moguluwa Shedrack Chinwuba, \\ Assosiate Proffesor, University of Nigeria, Nsukka \\ Okocha Ebere Rejoice, \\ Ph.D,-Evangel University Akaeze, Nigeria
}

\title{
INNOVATION IN SERVICE QUALITY MEASUREMENT: A CASE OF NIGERIAN HEALTHCARE SECTOR
}

Abstract. This paper summarizes the arguments and counterarguments within the scientific discussion on the issue of service quality measurement. The main purpose of the research is to bring innovation in the operationalization conceptualization of service quality dimensions to suit the Nigerian healthcare environment. Empirical studies and extant literature show intentions from the classical five-level SERVQUAL-model. The systematization of literary sources and approaches to solving the problems of service quality measurement show a significant deviation from the pioneer five-construct SERVQUAL model. The relevance of solving this scientific problem is to bring novelty to the existing models to suit the differing service environment. The problem considered in the article was solved by developing a new construct that forms part of the service quality dimension. The study empirically confirms the use of six-construct SERVQUAL model that is structured to measure service quality in the Nigerian healthcare sector. In the first part of the article, the conceptual overview of service quality and its dimensions were analysed with a critical review of recent and previous research on service quality. Based on the results of the empirical results, a new dimension was hypothesized. The second part deals with the gap in the literature and conceptual framework. The third part of the article describes the material and method that describes the respondents and instrument adopted in the validity of the new investigated dimension. Finally, the result of the factor analysis shows the significant service quality statements that validate explanation as a reliable dimension of service quality in healthcare. A 10-item questionnaire and service statements to test the validity of explanation was administered to respondents who are the outpatients of the eight hospitals sampled in the province of Umuahia and Aba metropolis.

Keywords: service quality, service expectation, explanation, innovation, healthcare, communication gap.

Introduction. Over the years, marketing scholars have defined service quality differently. Quality in the context of service is an elusive and abstract concept that is difficult to define and measure, Lee et al. (2000). Parasuraman (1988) defined service quality as the difference between predicted or expected service (customer expectation) and perceived service (customer perception). According to Gronroos (1990), healthcare quality has two distinct facets; namely technical quality and functional quality. Technical quality refers to the accuracy of medical diagnosis and procedures and is generally comprehensible to the professional community but not to the patients. While functional quality refers to the manner in which the healthcare service is delivered to the patients. In other words, technical quality is about what the customer gets, functional quality is about how they get it. Bowers (1994) opined that technical quality falls short of being a truly useful measure for describing how patients evaluate the quality of a medical service encounter. Although technical quality has high priority for patients, most patients do not have the knowledge to evaluate effectively the quality of the diagnostic and therapeutic intervention process or information necessary for such evaluation, as such is not shared with the patients. Thus, patients base their evaluation of quality on interpersonal and environmental factors, which medical professionals have always regarded as less important. Lam (1997).

The challenge of service quality measure in empirical terms was made easier service marketing research by the service quality model of Parasuraman et. al. (1985); Parasuraman et. al. (1988);

Cite as: Chinedum N., Chinwuba M. S., \& Rejoice O. E. (2019). Innovation in Service Quality Measurement: a Case of Nigerian Healthcare Sector. Marketing and Management of Innovations, 1, 143-150. http://doi.org/10.21272/mmi.2019.1-11 

Sector

Parasuraman et. al. (1991). The model is an operational instrument used to measure the service quality construct. It is a multi-item scale developed to asses customer perceptions of service quality in service and retail businesses. The scale decomposes the notion of service quality into five constructs as follows: Tangibility, Reliability, Responsiveness, Assurance, and Empathy. The limitation of this model has since being published with emphasis that the classical model of Parasuraman et.al $(1985 ; 1988)$ should not be generalized in all service sectors. (Vandamme and Leunis 1993; Bowers et. al. 1994; Demiral et.al., 2009)

One of the biggest challenges of healthcare management is to increase the value of the service rendered to their clients. Healthcare service-providers must know and understand what creates value for their clients. This should be an ongoing process as patients' patronage orientation changes over time. Also, in the contemporary service environment, it has always been a difficult task to determine what constitute service quality. Particularly, in the health-care services, there exist a gap between the service provider's perception of service quality and customer's (patients) perception of service quality. Customers' expectations in the service industry and healthcare, in particular, are based on past experiences (last call), the opinions of friends and healthcare information. The high expectation of patients in the healthcare industry creates a wide gap in measuring healthcare service quality. Many authors have done much work on service quality using Parasuraman model, but little has investigated the peculiarity of a service environment with the Parasuram's model. The traditional service quality model of Parasuraman, et al (1988) is not all-encompassing to all service firms. Service quality dimensions ought to be operationalized to suit the service sector investigated, culture (service policy), infrastructural development and level of literacy of the people. This research seeks to extend the dimensions of service quality variable in the Nigerian Healthcare sector.

Literature Review. Studies on service quality and customer satisfaction were found in native and foreign scientific papers: (Moguluwa et al., 2013; Okeke et al., 2005; Alabar et al.,2014; Ugboma et al., 2007; Sheetal and Harsh 2004; Choa-chan Wu 2011; Sower et al., 2001; Hossain, 2012; Joel and Carol 2006; Andaleeb. 2001; Figen and Ebru 2010; Yagci and Duman, 2006; Vandamme and Leunis 1993; Parasuraman et. al., 1985; Bitner et al., 1990; Lee at al., 2000; Demiral et.al., 2009).

A significant contribution to innovative and operationalized service quality measurement in the healthcare sector has been done by few authors namely Figen and Ebru (2010) Sower et al. (2001), Andaleeb (2001), Irfan and ljaz (2011), Vandamme and Leunis (1993). Despite many research on service quality, operationalizing service quality dimensions were not adequately investigated and applied. Differences in the service environment and the cultural gap had not been discussed extensively as factors that validate the research thought of operationalizing and conceptualizing service quality measurement to suit a particular environment and culture. On this premise, this research becomes relevant to fill this gap.

Today, as competition and cost increase, and as productivity and quality decrease, service firms face the task of increasing their competitive differentiation, service quality and productivity (Kolter, 2000). However, the issue of quality in service delivery basically relies on the customer's judgment. According to Grzinic (2007), quality as a concept is a complex term, made up of several element and criteria. All quality elements or criteria are equally important in order to obtain one hundred per cent quality. Today quality is the result of growing and increasingly diverse needs of the consumers, along with a highly increasing competition, market globalization and the development of modern technology. To ensure high-quality inservice delivery, Shahin (2005) opined that managers in the service sector must demonstrate that their services are customer focused and that continuous performance improvement is being delivered. It is essential that customer expectations are properly understood and measured. Wisniewski (2001) related that service quality is a concept that has aroused considerable interest and debate in the research literature because of the difficulties in both defining measuring it.

The conceptualized framework of this study is in consonance with the work of Vandamme and Leunis [1993], who identified two additional service quality dimensions in the healthcare sector namely «Caring» 
and «patient outcomes» to the five generic quality dimensions of SERVQUAL. The framework is fig.1 explained the conceptual item specification of service quality variables.

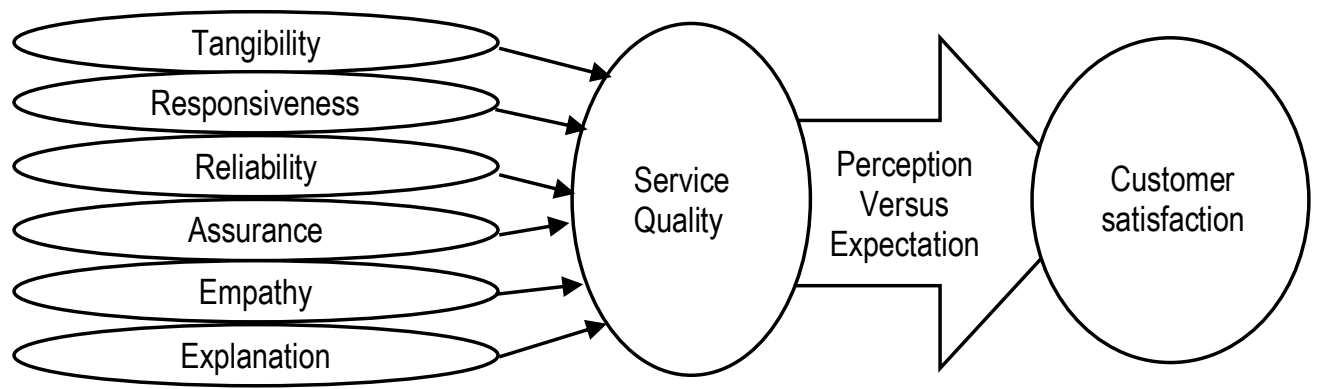

Figure 1. The conceptual framework of service quality

Source: compiled by authors.

Irfan and ljaz (2011) quoting Parasuraman et al (1985) explained the contextual item specification of service quality variables which are highlighted thus:

1. Tangibility here includes hygienic condition, sterilization of equipment, healthy environment, waiting facilities for patients, healthy and clean environment, availability of laboratories and pharmacy within the hospital premises.

2. Responsiveness: This service quality construct comprised of how the doctors, nurses and supporting staff respond to patients' call and availability of feedback mechanism and how the management responds to patient complaints.

3. Assurance: The third service quality construct in this study include doctor's expertise and skills about the field of specialization, qualified nurses and supporting staff, accurate laboratories and medical test results.

4. Reliability measures the ability of doctors and nurses to perform the promised service dependability and accurately.

5. Empathy represents the individual concern of doctors, staff, nurses and the management for patients in order to provide comfort to patients.

6. Explanation according to the study includes the ability of doctors and nurses to explain how long a procedure/delay would take, doctors keeping the patients in the know at all times, doctors and nurses explaining what they wish to do or about doing with some assurance as well as explaining medical procedure, implication of result and plan.

The empirical review of service quality in the health care environment is shown in Table 1.

The main purpose of the study is to assess the novelty of service measurement, while specifically; the research tends to investigate the validity of service explanation as a dimension of service quality measurement in the Nigerian health care environment in relation with the traditional service quality model of Parasuraman et al. (1985).

The survey design was employed in this study. A total of eight hospitals were sampled purposively in two metropolitan cities of Abia state, Nigeria. A multistage and convenient sampling technique was adopted in choosing the sampled hospitals and respondents for the study. Four public and four private hospitals were sampled to avoid any bias in the investigation. A pilot study carried out was used to determine the reliability of the instrument. Cronbach Alpha coefficient of 0.836 was realized indicating high internal consistency of the test instrument. 
N. Chinedum, M. S. Chinwuba, O. E. Rejoice. Innovation in Service Quality Measurement: a Case of Nigerian Healthcare Sector

Table 1. An empirical review of service quality in the health care environment

\begin{tabular}{|c|c|c|c|c|}
\hline Authors & Topic & $\begin{array}{c}\text { The instrument } \\
\text { for Data } \\
\text { Analysis }\end{array}$ & $\begin{array}{c}\text { Operationalize Service } \\
\text { Quality Dimension }\end{array}$ & Result \\
\hline $\begin{array}{l}\text { Vandamme, R } \\
\text { \& Leunis, J } \\
\text { (1993) }\end{array}$ & $\begin{array}{l}\text { Development of a } \\
\text { multiple-item scale for } \\
\text { measuring hospital } \\
\text { service quality }\end{array}$ & Factor analysis & Multiple-item scale & $\begin{array}{c}\text { The multiple-item } \\
\text { dimensions were all found } \\
\text { to have a significant } \\
\text { association to patient's } \\
\text { satisfaction }\end{array}$ \\
\hline $\begin{array}{c}\text { Andaleeb, S.S } \\
\qquad(2001)\end{array}$ & $\begin{array}{c}\text { Service quality } \\
\text { perception and } \\
\text { patient's satisfaction: a } \\
\text { study of hospitals in a } \\
\text { developing country } \\
\end{array}$ & Factor analysis & $\begin{array}{c}\text { Responsiveness, } \\
\text { Assurance, } \\
\text { Communication, } \\
\text { Discipline, Baksheesh }\end{array}$ & $\begin{array}{c}\text { The five-construct } \\
\text { dimensions were all found } \\
\text { to have a significant } \\
\text { association to patient's } \\
\text { satisfaction } \\
\end{array}$ \\
\hline $\begin{array}{c}\text { Sower et.al } \\
\text { (2001) }\end{array}$ & $\begin{array}{c}\text { The dimension of } \\
\text { service quality for } \\
\text { hospitals: Development } \\
\text { and use of the KQCAH } \\
\text { scale }\end{array}$ & $\begin{array}{l}\text { KQCAH } \\
\text { Instrument and } \\
\text { Factor analysis }\end{array}$ & $\begin{array}{c}\text { Repeat/caring, } \\
\text { Effectiveness, } \\
\text { Appropriateness, } \\
\text { Information, Efficiency, } \\
\text { Effectiveness, First } \\
\text { impression, Staff } \\
\text { diversity } \\
\end{array}$ & $\begin{array}{l}\text { The scale was found to be } \\
\text { more encompassing in } \\
\text { measuring service } \\
\text { performance }\end{array}$ \\
\hline $\begin{array}{c}\text { Figen, Y \& } \\
\text { Ebru, D (2010) }\end{array}$ & $\begin{array}{c}\text { Health care service } \\
\text { quality: a comparison } \\
\text { of public and private } \\
\text { hospitals }\end{array}$ & $\begin{array}{l}\text { Factor analysis } \\
\text { and Gap } \\
\text { analysis }\end{array}$ & $\begin{array}{l}\text { Reliability-confidence, } \\
\text { Empathy and Tangibles }\end{array}$ & $\begin{array}{l}\text { The three-construct } \\
\text { dimensions were the only } \\
\text { significant service quality } \\
\text { dimension in the health } \\
\text { care sector }\end{array}$ \\
\hline $\begin{array}{l}\text { Irfan, S.M \& } \\
\text { ljaz, A (2011) }\end{array}$ & $\begin{array}{c}\text { Comparison of service } \\
\text { quality between private } \\
\text { and public hospitals: } \\
\text { empirical evidence } \\
\text { from Pakistan } \\
\end{array}$ & $\begin{array}{l}\text { SERVQUAL } \\
\text { instrument and } \\
\text { t-test statistics }\end{array}$ & $\begin{array}{c}\text { Tangibles, assurance, } \\
\text { responsiveness, } \\
\text { empathy and timeliness. }\end{array}$ & $\begin{array}{c}\text { Service quality of private } \\
\text { hospitals was perceived to } \\
\text { be higher than public } \\
\text { hospitals }\end{array}$ \\
\hline
\end{tabular}

Source: compiled by authors.

Result. The result of this research from Table 2 shows the average mean of the service statement of six service quality dimensions namely Tangibility, Responsiveness, Assurance, Reliability, Empathy and Explanation.

Table 2. Descriptive Statistics of Service Quality Variable

\begin{tabular}{|c|c|c|c|c|c|}
\hline & Mean & Std. Deviation & Variance & Level of Satisfaction & Mean Range \\
\hline Tangibility & 3.6527 & .37617 & .142 & Satisfaction & $3-3.99$ \\
\hline Assurance & 3.9513 & .28441 & .081 & Satisfaction & $3-3.99$ \\
\hline Responsiveness & 4.2260 & .13224 & .017 & Highly satisfied & $4-5$ \\
\hline Empathy & 4.1300 & .15717 & .025 & Highly satisfied & $4-5$ \\
\hline Reliability & 3.2833 & .13451 & .018 & Satisfied & $3-3.99$ \\
\hline Explanation & 2.8267 & .03144 & .001 & Dissatisfied & $1-2.99$ \\
\hline
\end{tabular}

Source: analysed from field data.

Out of the expected mean of 5, 1-2.99 shows dissatisfaction, 3-3.99 shows satisfaction, while 4-5 shows highly satisfied. This means that explanation as an investigated variable did not meet customers' (patients) satisfaction. Patients are dissatisfied with way doctors and nurses explain procedures, results 
N. Chinedum, M. S. Chinwuba, O. E. Rejoice. Innovation in Service Quality Measurement: a Case of Nigerian Healthcare Sector

and what they wish to do this means that patients are not always on the know. There ought to be a serious improvement in this variable.

Table 3 shows the basic service quality statements that were investigated. The mean of column 5 of table 3 shows an average mean of public and private hospitals investigated. The mean shows are the Perceived Mean (PM), out of an Expected Mean (EM) of 5 points. Column 6 of Table 3 shows the level of satisfaction of the service statements. The only explanation was rated dissatisfied. The result validates the previous research results of Figen and Ebru (2010) Sower et al. (2001), Vandamme and Leunis (1993), that service quality variables should be operationalized to meet the environmental and social-cultural gap in our differing area of study.

Table 3. The mean rating of service statement and dimensions

\begin{tabular}{|c|c|c|c|c|c|}
\hline S/NO & Service quality statement & $\begin{array}{c}\text { Public } \\
\text { Hospital } \\
\text { (Mean) }\end{array}$ & $\begin{array}{c}\text { Private } \\
\text { Hospital } \\
\text { (Mean) }\end{array}$ & $\begin{array}{c}\text { Average } \\
\Delta \\
\text { Mean } \\
\end{array}$ & $\begin{array}{l}\text { Level of } \\
\text { Satisfaction }\end{array}$ \\
\hline 1 & 2 & 3 & 4 & 5 & 6 \\
\hline \multicolumn{6}{|c|}{ TANGIBILITY } \\
\hline 1 & The hospital was visually appealing & 4.66 & 3.20 & 3.93 & Satisfied \\
\hline 2 & Hospital premises were neat and clean & 4.46 & 3.76 & 4.11 & Highly satisfied \\
\hline 3 & There was enough waiting room/space & 4.40 & 1.82 & 3.11 & Satisfied \\
\hline 4 & Hospital had modem equipment & 4.46 & 2.52 & 3.49 & Satisfied \\
\hline 5 & Hospital had regular electricity & 4.60 & 2.40 & 3.5 & Satisfied \\
\hline 6 & Toilets and bathrooms were clean & 4.38 & 4.10 & 4.24 & Highly satisfied \\
\hline \multicolumn{6}{|c|}{ ASSURANCE } \\
\hline 7 & Doctors expertise and skills & 4.40 & 3.78 & 4.09 & Highly satisfied \\
\hline 8 & Doctors gave correct treatment at the first time & 2.96 & 3.94 & 3.45 & Satisfied \\
\hline 9 & $\begin{array}{c}\text { Doctors were competent in diagnosing the } \\
\text { problem }\end{array}$ & 4.02 & 4.30 & 4.16 & Highly satisfied \\
\hline 10 & You felt safe in the hand of the doctors & 4.48 & 3.78 & 4.13 & Highly satisfied \\
\hline 11 & Doctors go for expert opinion in critical cases & 4.24 & 4.58 & 4.03 & Highly satisfied \\
\hline \multicolumn{6}{|c|}{ RESPONSIVENESS } \\
\hline 12 & Doctors are willing to answer questions & 3.98 & 4.00 & 3.99 & Satisfied \\
\hline 13 & Doctors listened to you attentively & 4.08 & 4.56 & 4.32 & $\begin{array}{l}\text { Highly } \\
\text { satisfied }\end{array}$ \\
\hline 14 & Doctors and nurse were consistently caring & 3.92 & 4.44 & 4.18 & $\begin{array}{l}\text { Highly } \\
\text { satisfied }\end{array}$ \\
\hline 15 & $\begin{array}{l}\text { Nurses communicated your problems to } \\
\text { doctors }\end{array}$ & 4.02 & 4.60 & 4.31 & $\begin{array}{l}\text { Highly } \\
\text { satisfied }\end{array}$ \\
\hline 16 & Nurses paid individual attention to patients & 4.22 & 4.44 & 4.33 & $\begin{array}{l}\text { Highly } \\
\text { satisfied }\end{array}$ \\
\hline \multicolumn{6}{|c|}{ EMPATHY } \\
\hline 17 & Doctors and nurses provided moral courage & 4.14 & 4.52 & 4.33 & $\begin{array}{l}\text { Highly } \\
\text { satisfied }\end{array}$ \\
\hline 18 & $\begin{array}{l}\text { Doctors/Nurses efficiently respond to the } \\
\text { patients }\end{array}$ & 4.12 & 4.48 & 4.30 & $\begin{array}{l}\text { Highly } \\
\text { satisfied }\end{array}$ \\
\hline 19 & There was a feedback mechanism & 4.40 & 3.20 & 3.95 & Satisfied \\
\hline 20 & $\begin{array}{l}\text { Doctors and nurses cared for patient } \\
\text { cordially whenever called }\end{array}$ & 4.58 & 3.50 & 4.04 & $\begin{array}{l}\text { Highly } \\
\text { satisfied }\end{array}$ \\
\hline 21 & $\begin{array}{c}\text { You were comfortable with doctors and } \\
\text { nurse services }\end{array}$ & 3.64 & 4.42 & 4.03 & $\begin{array}{l}\text { Highly } \\
\text { satisfied }\end{array}$ \\
\hline
\end{tabular}


N. Chinedum, M. S. Chinwuba, O. E. Rejoice. Innovation in Service Quality Measurement: a Case of Nigerian Healthcare Sector

\begin{tabular}{|c|c|c|c|c|c|}
\hline & & & & \multicolumn{2}{|c|}{ Continue Table 3} \\
\hline 1 & 2 & 3 & 4 & 5 & 6 \\
\hline \multicolumn{6}{|c|}{ RELIABILITY } \\
\hline 22 & $\begin{array}{c}\text { Doctors and nurses did exactly what they } \\
\text { promise }\end{array}$ & 3.92 & 2.44 & 3.18 & Satisfied \\
\hline 23 & Doctors were sincere whenever necessary & 3.32 & 3.08 & 3.20 & Satisfied \\
\hline 24 & Doctors dependably carry their duties & 3.14 & 3.80 & 3.47 & Satisfied \\
\hline \multicolumn{6}{|c|}{$\begin{array}{ll}\text { EXPLANATION } \\
\end{array}$} \\
\hline 25 & $\begin{array}{l}\text { Doctors/Nurses explain how long a } \\
\text { procedure/delay would take }\end{array}$ & 2.96 & 2.64 & 2.80 & Dissatisfied \\
\hline 26 & $\begin{array}{l}\text { Doctors explain what he wishes to do or } \\
\text { about doing with some assurance }\end{array}$ & 2.82 & 2.80 & 2.81 & Dissatisfied \\
\hline 27 & $\begin{array}{l}\text { Doctors explain medical procedures, } \\
\text { implication and result }\end{array}$ & 2.80 & 2.94 & 2.87 & Dissatisfied \\
\hline
\end{tabular}

Source: analysed from field data

The findings of factor loading, Cronbach reliability and Level of significance are shown in Table 4.

Table 4. Construct measurement

\begin{tabular}{|l|c|c|c|}
\hline \multicolumn{1}{|c|}{ Service explanation [SE] } & $\begin{array}{c}\text { Factor } \\
\text { loading }\end{array}$ & $\begin{array}{c}\text { Cronbach } \\
\text { reliability }\end{array}$ & $\begin{array}{c}\text { Level of } \\
\text { significance }\end{array}$ \\
\hline 1. Doctors explain how long a procedure/delay would take & 0.867 & .892 & significant \\
\hline 2. Doctors keep the patients on the known & 0.432 & .922 & insignificant \\
\hline 3. Doctors and nurses explain what they wish to do & 0.609 & .866 & significant \\
\hline 4. Doctors explain the meaning of the medical results & 0.814 & .901 & significant \\
\hline 5. Doctors and nurses explain service procedures. & 0.765 & .822 & significant \\
\hline 6. Doctors and nurses explain prescription & 0.433 & .790 & insignificant \\
\hline 7. Doctors and nurses explain the operational queuing system & 0.478 & .881 & insignificant \\
\hline 8. Doctors and nurses explain the service charge in detail & 0.670 & .826 & significant \\
\hline 9. Doctors and nurses explain reasons for service failure & 0.945 & .769 & significant \\
\hline 10. Doctors and nurses explain innovation in service delivery & 0.785 & .980 & significant \\
\hline
\end{tabular}

Note: 0-0.49 is insignificant.

Source: analysed from field data.

The factor analysis tested a 10 -item loaded construct statement that measured the validity of service explanation. 7 items were found to be significant. The Cronbach reliability shows that the measuring instrument is good and fit to measure service explanation as a service quality measurement.

Conclusions and Directions for future researches. The research result showed a significant counter view of dimensionality and measurement of service quality from scholars, especially health care service researchers. The Parasuraman et al. (1985) scale of SERVQUAL was a breakthrough instrument in measuring service quality but lack the validity to generalized to all service environment. The foremost issue in conceptualization and operationalization of service quality is what patients/customers perceive as the essential dimensions of hospital service quality provided by the hospitals. The SERVQUAL literature discovered five key service quality factors: tangibility, reliability, responsiveness, empathy, assurance. The development of explanation as a hospital service quality dimension by the researcher was in agreement 
with the results of the following researchers: (Vandamme and Leunis 1993; Andaleeb, 2001; Figen and Ebru 2010; Sower et al. 2001) who maintained that SERVQUAL dimension of Parasuraman et al. (1985) should not be generalized to every service firm. Bowers et al. The investigation and research on the dimensionality of service quality is inexhaustible. In this research, more should be done to investigate more on the effect of post-hospital communication on patient's satisfaction and retention. This will close the communication gap which Explanation tries to fill.

\section{References}

Alabar, T.T., Egena, O. \& Gbande, R.I (2014). Service quality and customer satisfaction in Nigerian mobile telephone. Proceedings of $3^{\text {rd }}$ International Conference on Business Management and Governance, Singapore. IPEDR Vol. (82)

Andaleeb, S. S. (2001). "Service quality perceptions and patient satisfaction: a study of hospitals in a developing country». Social Science \& Medicine 52(9): 1359-1370.

Bitner, M. J. (1990). Evaluating service encounters, the effect of physical surroundings and employee responses. Journal of Marketing.Vol.5, pp.69-82.

Bowers, M. R., Swan, J. E., \& Koehler, W. F. (1994). What attributes determine quality and satisfaction with health care delivery?.Health Care Manage. Rev., 19(4):49-55.

Chao-chan, w. (2011). The impact of hospital brand image on service quality, patient satisfaction and loyalty.African Journal of Business Management.Vol.5(12)

Demiral, Y., Yoldas, M. A \&Divanoglu, S.U (2009). The determinants of service quality satisfiers and dissatisfiers.International Journal of Service.Industrial. Manage. Vol. 6(5)

Figen, Y \&Ebru, D. (2010). Healthcare service quality: a comparism of public and private hospitals. African Journal of business Management.4(6), 962-97.

Grönroos, C. (1990). Service management and marketing: managing the moments of truth in service competition. USA: Lexington Books.

Grzinic, J. (2007). Concept of service quality measurement in hotel industry: DBK

Hossain, M.J. (2012). Impact of service quality on customer satisfaction: a case of tourism industry in Bangladesh. International Journal of Research in Finance \& Marketing. Vol.2 (2).

Irfan, S.M., \& ljaz, A. (2011). Comparism of service quality between private and public hospitals: empirical evidence from Pakistan. Journal of Quality and Technology Management. Vol. 7, 1-22.

Joel, E.C., \& Carol. C.B. (2006). Measuring service quality in e-retailing. Journal of Service Research. Vol. (8) 3.

Kotler. P. (2000). Marketing management: Analysis, planning, implementation and control. 9th Ed. New Delhi: Prentice-Hall.

Lam, S.S.K. (1997). SERVQUAL: A tool for measuring patient's opinons of hospital service quality in Hongkong. Total Quality Management. Vol. (3), 145-52.

Lee, H., Delene, L.M., Bunda, M.A., \& Kim, C. (2000). Methods of measuring health-care service quality. Journal of Business Research. Vol. (48) 2, 33-46.

Moguluwa, S.C., \& Ode, E. (2013). Evaluating customer perceived service quality and customer satisfaction in the banking industry. Far. East Journal of Psychology and Business. Far-East Research Center. Vol. (11) 3

Okeke, T.C., Ezeh, G.A., \& Ugochukwu, N.O.A. (2005). Service quality dimensions and customer satisfaction with online services of Nigerian banks. Journal of Internet Banking and Commerce. Vol. (20) 116.

Parasuraman, A., Valarie, A.Z., \& Leonard, L.B. (1985). A conceptual model of service quality and the implications for future research. Journal of Marketing. Vol. (49), 41-50.

Parasuraman, A., Berry, L. L., \& Zeithaml, V. A. (1988). SERVQUAL: A multiple-term scale for measuring customer perceptions of service Quality report.

Parasuraman, A., Valarie, A.Z., \& Leonard, L.B. (1991). An empirical examination of relationships in an extended service quality model. Marketing Science Institute, Cambridge, MA.

Sheetal, B.S., \& Harsh, V.V. (2004). Relative importance of service quality dimensions: a multi-sectional study. Journal of Service Research. Vol. (9).

Shahin, A. (2005). SERVQUAL and model of service quality gaps: a framework for determining and prioritizing critical factors in delivery service. Department of Management, University of Isfahan. Iran.

Sower, V.D.J., Kilbourne, W.K., Kohers, G., \& Jones, P. (2001). The dimensions on service quality for hospitals: Development and use of the KQCAH scale. Health care Management Review. Vol. (26) 2. 47-59.

Ugboma, C., Ogwude, I.C., Ugboma, O., \& Nnadi, K. (2007). Service quality and satisfaction measurement in Nigeria Port: an exploration. Journal of Maritime Policy and Management. Vol. (34) 4.

Vandamme, R., \& Leunis, J. (1993). Development of a multi-item scale for measuring hospital service quality. International Journal of Service and Industrial Management. Vol.33 
N. Chinedum, M. S. Chinwuba, O. E. Rejoice. Innovation in Service Quality Measurement: a Case of Nigerian Healthcare Sector

Wisnieski, M. (2001). Using SERVQUAL to access Customer Service Satisfaction with Public Sector Services, Journal of Service Quality, Vol.11, No 6, pp.380-388.

Yaci, M.l., \& Duman, T. (2006). Perceived service quality in healthcare organization and a research in Ankara by hospital type. Journal of Ankara Studies

Н. Чінедум, Сільськогосподарський університет Михаеля Окпара (Нігерія);

М. Ш. Чінбува, доцент, Університет Нігерії (Нігерія);

O. E. Рейойc, Ph.D, Євангельський університет Акаезе (Нігерія).

Інновації в оцінці якості послуг: на прикладі сектору охорони здоров'я в Нігерії

У статті авторами систематизовано основні передумови фрормування науково-практичних підходів до оцінки якості надання послуг у сфері охорони здоров'я. Основною метою дослідження $\epsilon$ аналіз можливостей застосування інноваційних підходів при формуванні механізму оцінки якості надання послуг, враховуючі сучасні особливості системи охорони здоров'я Нігерії. Авторами систематизовано теоретико-методичні підходи та емпіричні дослідження щодо особливостей формування класичної п'ятирівневої SERVQUAL-моделі оцінки якості наданих послуе. Результати аналізу свідчать, що традиційна п'ятирівнева SERVQUAL-модель зазнала значних трансформацій у відповідності до сучасник умов функціонування ринку послуе. Авторами обгрунтовано необхідність подальшого дослідження можливостей застосування інноваційних підходів при модернізації SERVQUAL-моделі з метою використання ії у різних секторах економіки. Так, у статті запропоновано використовувати шестирівневу SERVQUAL-моделі оцінки якості надання послуг у системі охорони здоров'я Нігерії. Авторами висунуто та перевірено гіпотезу щодо адекватності використання запропонованої шестирівневої SERVQUAL-моделі при оціниі якості надання послуг у системі охорони здоров'я Нігері. Інформаційною базою дослідження стали результати анкетування респондентів (пацієнтів) восьми лікарень провінції Умуахія та міста Аба. Авторами було розроблено анкету з десяти питань для оцінки якості послуг у вищезазначених лікарнях. Отримані емпіричні результати підтверджують адекватність використання шестирівневої SERVQUAL-моделі для оцінки якості обслуговування у сфрері охорони здоров'я Нігерії. При иьому авторами наголошено, що найбільщ статистично значимим фактором $є$ надання персоналом клініки пояснень щодо медичних послуг та процедур, що будуть надані пацієнтам. Також проведений фракторний аналіз підтвердив, що фрактор - якість надання послуг є статистично значимим при оцінці якості послуг у сфері охорони здоров'я Hizepiï.

Ключові слова: якість послуг, очікування від послуг, пояснення, інновації, охорона здоров'я, комунікації.

Manuscript received: 17.01 .19

(c) The author(s) 2019. This article is published with open access at Sumy State University. 